\title{
Electrochemical Hydrogen Peroxide Production in Acidic Medium Using a Tubular Photo-reactor: Application in Advanced Oxidation Processes
}

\author{
Juan M. Peralta-Hernández, ${ }^{1, *}$ and Luis A. Godínez ${ }^{2}$ \\ ${ }^{1}$ Centro de Innovación Aplicada en Tecnologías Competitivas (CIATEC), Departamento de Investigación y Posgrado, Omega- \\ 201, Fraccionamiento Industrial Delta. León, 37545, Guanajuato, México, jperalta@ciatec.mx \\ 2 Centro de Investigación y Desarrollo Tecnológico en Electroquímica, Parque Tecnológico Querétaro-Sanfandila, Pedro \\ Escobedo, 76703, Querétaro, México.
}

Received January 23 ${ }^{\text {rd }}, 2014$; Accepted April 23 ${ }^{\text {rd }}, 2014$.

\begin{abstract}
This paper describes the results obtained in the design and characterization of a tubular electrochemical reactor. The set-up was employed for on-site hydrogen peroxide $\left(\mathrm{H}_{2} \mathrm{O}_{2}\right)$ production in an acidic medium ( $\mathrm{pH} 3$ ) to promote three electrochemical advanced oxidation processes (EAOP): electro-Fenton (EF), photoelectro-Fenton $(\mathrm{PEF})$ and photocatalysis treatment $(\mathrm{PT})$. These processes were evaluated by their abilities to degrade a commercial dye, Orange-II (OGII), in solution using total organic carbon (TOC) removal and high performance liquid chromatography (HPLC). To have free solutions of iron in the EF and PEF systems, a Nafion ${ }^{\mathrm{TM}}$ membrane with dispersed iron was prepared. For use in photocatalysis, electrodes with a large superficial area were prepared by coating carbon cloth fiber supports with titanium dioxide $\left(\mathrm{TiO}_{2}\right)$ using the electrophoretic (EP) method. In this work, wastewater samples with a large number of microorganisms (coliform bacteria) were treated with this new reactor design.
\end{abstract}

Key Words: Electro-Fenton, Photoelecto-Fenton, Hydrogen peroxide, Photoelectrochemistry, Electrochemical reactor, Disinfection.

\section{Introduction}

Hydrogen peroxide $\left(\mathrm{H}_{2} \mathrm{O}_{2}\right)$ is currently one the most common chemicals used for water treatment and chemical production, and it is a promising oxidant for green chemistry processes in the near future $[1,2,3]$. The use of $\mathrm{H}_{2} \mathrm{O}_{2}$ may offer an efficient alternative for controlling pollution in aqueous media. Hydrogen peroxide is one the most popular non-selective oxidizing agents that are used to convert organic compounds to carbon dioxide and water [4]. Recently, several works have demonstrated that on-site electrochemical generation of $\mathrm{H}_{2} \mathrm{O}_{2}$ can be used successfully to decontaminate water treatment effluents with different organic compounds [5-8]. In this process, $\mathrm{H}_{2} \mathrm{O}_{2}$ is continuously supplied to the contaminated solution through oxygen $\left(\mathrm{O}_{2}\right)$ reduction by two electrons in an acidic medium, according to the following equation [9-12]:

$$
\mathrm{O}_{2}+2 \mathrm{H}^{+}+2 \mathrm{e}^{-} \rightarrow \mathrm{H}_{2} \mathrm{O}_{2}
$$

The most common use of $\mathrm{H}_{2} \mathrm{O}_{2}$ in environmental applications involves the addition of iron $\left(\mathrm{Fe}^{2+}\right)$ to the acidic solution to increase the oxidizing power of the $\mathrm{H}_{2} \mathrm{O}_{2}$ by forming hydroxyl radicals $\left({ }^{\circ} \mathrm{OH}\right)$ via the Fenton reaction, according to the equation $[13,14]$.
Resumen. En este trabajo se describen los resultados obtenidos en el diseño y la caracterización de un reactor electroquímico tubular. Dicho reactor se usó para llevar a cabo la producción in situ de peróxido de hidrógeno $\left(\mathrm{H}_{2} \mathrm{O}_{2}\right)$ en medio ácido $(\mathrm{pH} 3)$ para promover tres procesos electroquímicos de oxidación avanzada (PEOA): electro-Fenton (EF), fotoelectro-Fenton (FEF) y fotocatálisis (FC). Estos procesos fueron evaluados por su capacidad para degradar un colorante comercial, Naranja-II (N-II), en solución. Para ello, se realizaron determinaciones de carbono orgánico total (COT) así como de cromatografía líquida de alta resolución (CLAR). Para tener soluciones libres de hierro en los procesos EF y FEF, se preparó una membrana Nafion ${ }^{\mathrm{R}}$ con hierro disperso. Para las pruebas fotocatalíticas se desarrollaron electrodos con una gran área superficial que se prepararon mediante el recubrimiento con dióxido de titanio $\left(\mathrm{TiO}_{2}\right)$ de una tela de fibra de carbono usando el método electroforético (ME). Además se trabajó con muestras de agua residual con un gran número de microorganismos (bacterias coliformes) la cual fue tratada con este nuevo diseño de reactor.

Palabras clave: Electro-Fenton, fotoelecto-Fenton, peróxido de hidrógeno, fotoelectroquímica, reactor electroquímico, Desinfección.

$$
\mathrm{Fe}^{2+}+\mathrm{H}_{2} \mathrm{O}_{2} \rightarrow \mathrm{Fe}^{3+}+\cdot \mathrm{OH}+{ }^{-} \mathrm{OH}
$$

This method is commonly referred to as electro-Fenton (EF) treatment and is considered an advanced oxidation process (AOP) [15]. The principal reason for combining on-site hydrogen peroxide generation and the Fenton reaction is to improve the oxidation capacities of the two individual processes, creating a synergetic system [16]. The hydroxyl radical species that are produced through these processes are characterized by a large oxidation power $(2.8 \mathrm{~V} v s \mathrm{ENH})$ [17] that is able to transform organic compounds into $\mathrm{CO}_{2}$ and $\mathrm{H}_{2} \mathrm{O}$ [18].

Similarly, another type of AOP is the photoelectro-Fenton (PEF) system, in which the peroxide-ferrous system is illuminated with UV light, and Reactions 3 and 4 take place in addition to Equation 2, increasing the production of hydroxyl radicals and improving the oxidation of organic compounds [19].

$$
\begin{gathered}
\mathrm{Fe}^{2+}+\cdot \mathrm{OH} \rightarrow(\mathrm{FeOH})^{2+} \\
(\mathrm{FeOH})^{2+}+\mathrm{h} \nu \rightarrow \mathrm{Fe}^{2+}+\cdot \mathrm{OH}
\end{gathered}
$$

This catalytic process is achieved by $\mathrm{Fe}^{2+}$ regeneration, which takes place primarily by the reduction of $\mathrm{Fe}^{2+}$ species 
by $\mathrm{H}_{2} \mathrm{O}_{2}$. When UV light is used, the mineralization process can be accelerated by the photolysis of complexes of $\mathrm{Fe}^{3+}$ with some oxidation products and improvement in $\mathrm{Fe}^{2+}$ regeneration from the additional photoreduction of $\mathrm{Fe}^{3+}$ species through Equation 4 [19].

In the case of the EF and PEF systems, the iron species represent a serious problem during organic compound oxidation in a homogeneous medium. The removal of iron ions is an easy process that can be carried out by precipitation or re-dissolution of the iron ions after the treatment, but these operations generate additional costs in the treatment [20].

However, in the recent years, the use of Nafion ${ }^{\mathrm{TM}}$ membranes covered with highly dispersed iron ions has been the focus of several studies because the iron-coated $\mathrm{Nafion}^{\mathrm{TM}}$ membrane has a similar effect on $\mathrm{H}_{2} \mathrm{O}_{2}$ decomposition as the iron ions in a homogeneous solution [20,21,22]. The iron ions that are supported on the membrane allow the oxidation of the organic compounds through UV irradiation while avoiding the need for an expensive separation step [20].

In addition to the Fenton-related technologies, the photocatalytic process has become a commonly used technology because it can completely remove organic compounds [23]. Titanium dioxide $\left(\mathrm{TiO}_{2}\right)$ is the most common semiconductor material for photocatalytic processes, and it has been applied in several photocatalytic water treatment studies $[24,25]$. The inherent advantages of this material are its low cost, its low toxicity, its good photocatalytic properties, and its particularly wide band gap $(3.2 \mathrm{eV})$, which results in good stability and prevents photo-corrosion [26]. When $\mathrm{TiO}_{2}$ nanoparticles are subjected to radiation with sufficient energy, an electron is promoted from the valence band to the conduction band of the semiconductor, as indicated in Equation 5:

$$
\mathrm{TiO}_{2}+\mathrm{h} v \rightarrow e_{c b}^{-}+\mathrm{h}_{v b}^{+}
$$

The positively charged vacancy or hole $\left(h^{+}\right)$thus generated can react with either adsorbed water or hydroxyl ions to produce the powerful ${ }^{\circ} \mathrm{OH}$ radical, as shown in Equations 6 and 7.

$$
\begin{gathered}
\mathrm{h}_{v b}^{+}+\mathrm{H}_{2} \mathrm{O} \rightarrow \cdot \mathrm{OH}+\mathrm{H}^{+} \\
\mathrm{h}_{v b}^{+}+\mathrm{OH}^{-} \rightarrow \cdot \mathrm{OH}
\end{gathered}
$$

Furthermore, if an organic pollutant, $\mathrm{R}$, is adsorbed on the semiconductor surface, the hole can directly oxidize that species, as outlined in Equation 8 [27].

$$
\mathrm{h}_{v b}^{+}+\mathrm{R} \rightarrow \mathrm{R}_{o x}^{+}
$$

At the same time, the electrons that are photo-injected into the conduction band can react with dissolved $\mathrm{O}_{2}$ to produce $\mathrm{H}_{2} \mathrm{O}_{2}$, according to Equation 1, or they may be lost by recombination reactions with either unreached holes or with adsorbed ${ }^{\bullet} \mathrm{OH}$ radicals, as indicated in Equations 9 and 10, respectively [28].

$$
\begin{gathered}
\mathrm{e}_{c b}^{-}+h_{v b}^{+} \rightarrow \mathrm{TiO}_{2}+\text { heat } \\
\mathrm{TiO}_{2}\left(\mathrm{e}_{c b}^{-}\right)+{ }^{\cdot} \mathrm{OH}_{\mathrm{ads}} \rightarrow \mathrm{TiO}_{2}+{ }^{-} \mathrm{OH}_{\mathrm{ad}}
\end{gathered}
$$

If the semiconductor is used as an anode, those electrons can be extracted to the external circuit, retarding Equations 9 and 10.

Because $\mathrm{TiO}_{2}$ is a suspended powder, the reactor design should be efficient to avoid problems related to illumination limitations, mass transfer and nanoparticle recovery at the end of the treatment process $[29,30]$. One promising way to overcome such problems is to immobilize the catalyst $[11,29]$. In this method, mass transfer limitations are reduced by using microfibers as a direct support for the $\mathrm{TiO}_{2}$, and the illumination source is placed directly over the $\mathrm{TiO}_{2}$-covered face of the support.

The aim of this work is to compare the effectiveness of several of these water-treatment processes by studying the degradation of the azo dye Orange-II (OG-II) using high performance liquid chromatography (HPLC) and total organic carbon (TOC) analysis on water containing microorganisms. Tests were carried out using a continuous flow reactor that was operated to produce on-site $\mathrm{H}_{2} \mathrm{O}_{2}$ using the $\mathrm{EF}$ and the PEF processes. In addition, a Nafion ${ }^{\mathrm{TM}}$ membrane with iron fixed in the lattice and a $\mathrm{TiO}_{2}$-covered carbon cloth were incorporated to promote photocatalytic events and improve the oxidation of the organic compounds and microorganisms in the medium.

\section{Experimental details}

The chemicals used in this work, such as sulfuric acid $\left(\mathrm{H}_{2} \mathrm{SO}_{4}\right)$, sodium sulfate $\left(\mathrm{Na}_{2} \mathrm{SO}_{4}\right)$, and ferrous sulfate $\left(\mathrm{FeSO}_{4} \cdot 7 \mathrm{H}_{2} \mathrm{O}\right)$, were purchased from J.T. Baker as ACS reagent grade and were used as received, without further purification. Titanium (IV) oxysulfate $\left(\mathrm{TiOSO}_{4}, 99.99 \%\right.$, ca. 15 wt. diluted sulfuric acid solution) and the azo dye OG II $\left(\mathrm{C}_{16} \mathrm{H}_{11} \mathrm{~N}_{2} \mathrm{NaO}_{4} \mathrm{~S}, \lambda_{\max }=\right.$ $487 \mathrm{~nm}$, reagent grade) were purchased from Sigma-Aldrich. The carbon cloth and Nafion ${ }^{\mathrm{TM}}$ membrane were provided by ElectroChem Inc.

\section{Electrochemical photo-reactor}

The experiments were performed in an annular flow reactor containing a graphite cloth cathode (geometrical area of 90 $\mathrm{cm}^{2}$ ) and a $\mathrm{TiO}_{2}$-covered graphite cloth anode (geometrical area of $100 \mathrm{~cm}^{2}$ ), as shown in Figure 1. Additional studies are being carried out using the same reactor design with minor modifications in the capacity and anode materials [15].

The reactor volume was $0.5 \mathrm{~L}$, and the total solution volume, including that held in a reservoir stirred and sparged with pure $\mathrm{O}_{2}$, was $27 \mathrm{~L}$. In this set-up, a diaphragm pump (Shurflo) was used to create three flow rates, $56 \mathrm{~L} / \mathrm{h}, 76 \mathrm{~L} / \mathrm{h}$ and $96 \mathrm{~L} / \mathrm{h}$. Prior to the Fenton-reagent oxidation tests, a ferrous sulfate solution was added to make an $\mathrm{Fe}^{2+}$ concentration of either 0.02 


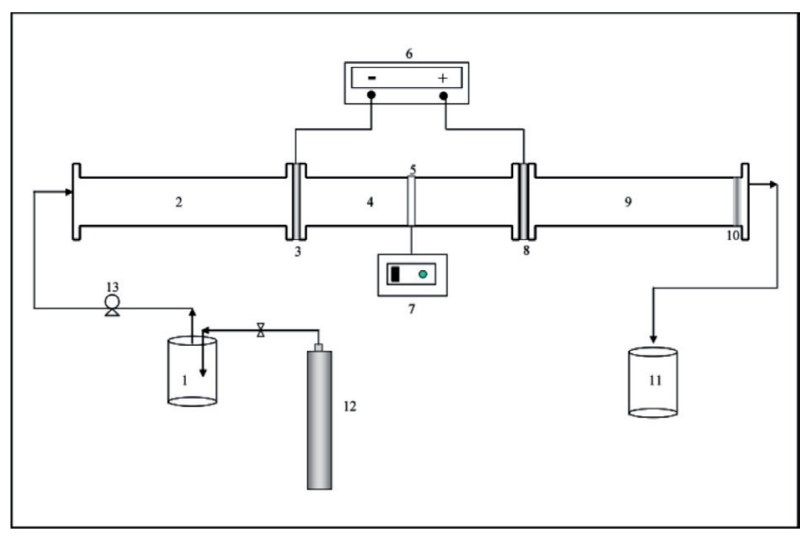

Figure 1. Diagram of the experimental photo-electrochemical reactor. 1) Deposit, 2) Inlet chamber, 3) Carbon cloth cathode, 4) Photo-chamber, 5) UV lamp, 6) Power supply, 7) UV lamp power supply, 8) $\mathrm{TiO}_{2}$ carbon cloth anode, 9) Outlet chamber, 10) Nafion $^{\mathrm{TM}}$ membrane with dispersed $\mathrm{Fe}^{2+}, 11$ ) Deposit exit, 12) Oxygen supply, 13) Pump.

or $0.05 \mathrm{mM}$. In the photo-assisted experiments, the illumination was provided by a low-pressure UV mercury lamp (UVP Inc., $\mathrm{P}=75 \mathrm{~mW} / \mathrm{cm}^{2}, \lambda=365 \mathrm{~nm}$ ). The assays were carried out under galvanostatic conditions with a GW Model:GPR1820 HD power supply.

\section{Evaluation of on-site $\mathrm{H}_{2} \mathrm{O}_{2}$ production}

Electrolysis experiments were carried out to test the capacity of the reactor to produce $\mathrm{H}_{2} \mathrm{O}_{2}$ through the cathodic reduction of dissolved $\mathrm{O}_{2}$ in a $0.05 \mathrm{M}$ solution of $\mathrm{Na}_{2} \mathrm{SO}_{4}$, adjusted to a $\mathrm{pH}$ of 3 with $\mathrm{H}_{2} \mathrm{SO}_{4}$ and saturated with $\mathrm{O}_{2}$. The $\mathrm{pH}$ of the solution was determined with a glass-electrode $\mathrm{pH}$ meter (Corning 320). The concentration of $\mathrm{H}_{2} \mathrm{O}_{2}$ created during electrolysis was determined by titrating with titanium (IV) oxysulfate and measuring the intensity of the color of the $\mathrm{H}_{2} \mathrm{O}_{2}$ - reagent complex at a wavelength of $406 \mathrm{~nm}$ [31].

\section{OG-II solution preparation}

An accurately weighed quantity of the OG-II dye was dissolved in distilled water to prepare a stock solution $(100 \mathrm{mg} / \mathrm{L})$, and experimental solutions of the desired concentration $(50 \mathrm{mg} / \mathrm{L})$ were obtained by successive dilution. The synthetic textile dye wastewater solution was prepared in accordance with previous reports [28] in which dye concentrations ranging between 10 and $200 \mathrm{mg} / \mathrm{L}$.

\section{Analytical procedure}

The degradation of OG-II was monitored by HPLC analysis, using a Hewlett Packard Series 1050 machine, equipped with a UV/Vis Detector and a reverse phase C-18 Phenomenex (LUNA 5 micron-C-18, $3 \times 150 \mathrm{~mm}$ ) column. The injection volume was $20 \mu \mathrm{L}$. The column was eluted with an ammonium acetate $(20 \mathrm{mM}) /$ acetonitrile $68: 32(\mathrm{v} / \mathrm{v})$ mixture with a flow rate of $0.5 \mathrm{~mL} / \mathrm{min}$ [24]. The TOC of the initial electrolyzed samples was determined with a TOC-VSCN (Shimadzu Co) analyzer.

\section{Nafion $^{\mathrm{TM}}$ membrane preparation}

The Nafion ${ }^{\mathrm{TM}}$ membrane (EC-NM-117) was exchanged with $\mathrm{FeCl}_{3} \cdot 6 \mathrm{H}_{2} \mathrm{O}$ (Fluka) at room temperature for a few minutes, after which the Nafion ${ }^{\mathrm{TM}}$ was immersed in $\mathrm{HCl}$. After the ion exchange, the membrane was washed with water and then immersed in $1 \mathrm{M} \mathrm{NaOH}$ to hydrate the $\mathrm{Fe}^{3+}$ ions, in accordance with Fernandez et al. [21]. For the $\mathrm{TiO}_{2}$-covered carbon cloth electrodes, nano-particulated $\mathrm{P} 25 \mathrm{TiO}_{2}(80 \%$ anatase, $20 \%$ rutile, average particle diameter $20 \mathrm{~nm}$ ), purchased from Degussa was used. The nanoparticles were deposited according to the methodology proposed by Manríquez and Godínez [32]. Scanning electron microscopy (SEM) of the $\mathrm{TiO}_{2}$ electrode surfaces was carried out using a JEOL-5400LV microscope.

\section{Results and discussion}

\section{Electrochemical generation of $\mathrm{H}_{2} \mathrm{O}_{2}$ in the photo-reactor at different flow rates}

Several tests were performed to evaluate the electrochemically generated $\mathrm{H}_{2} \mathrm{O}_{2}$ concentration in the reactor at different current densities $(\mathrm{j})$ and flow rates $(\mathrm{Q})$. The capacity of the system to electrochemically generate $\mathrm{H}_{2} \mathrm{O}_{2}$ at the carbon cloth cathode through $\mathrm{O}_{2}$ reduction (Eq. 1) was studied spectrophotometrically. Figure 2 shows the variation of the $\mathrm{H}_{2} \mathrm{O}_{2}$ concentration as a function of the electrolysis time and current densities with a flow rate of $56 \mathrm{~L} / \mathrm{h}$. Curve 2(A) corresponds to a sample in which the current density was $100 \mathrm{~mA} / \mathrm{cm}^{2}$; in this case, the $\mathrm{H}_{2} \mathrm{O}_{2}$ concentration was approximately $39 \mathrm{mg} / \mathrm{L}$ after a reaction time of $180 \mathrm{~min}$. Curve 2(B) corresponds to a current density of $200 \mathrm{~mA} / \mathrm{cm}^{2}$, and the resulting $\mathrm{H}_{2} \mathrm{O}_{2}$ accumulation was approximately $89 \mathrm{mg} / \mathrm{L}$ after $180 \mathrm{~min}$ of electrolysis. Finally,

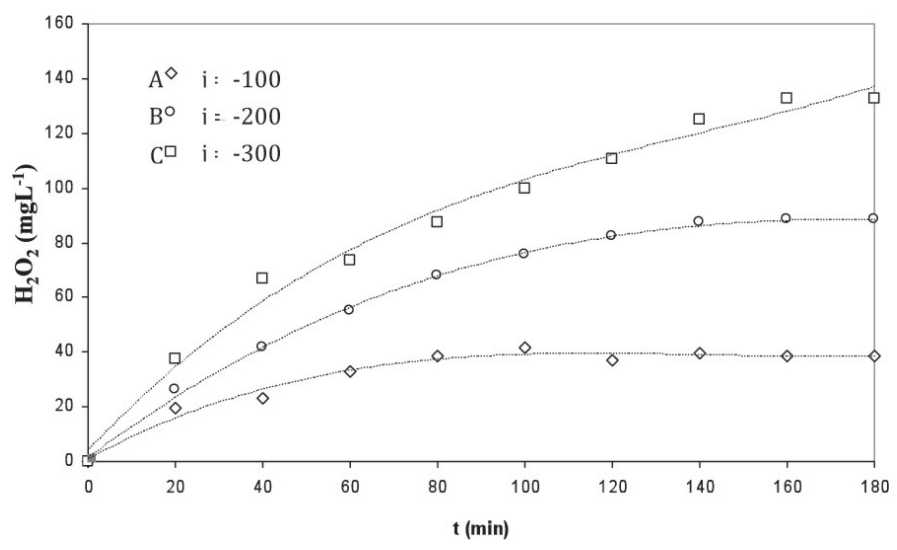

Figure 2. $\mathrm{H}_{2} \mathrm{O}_{2}$ production in the photo-electrochemical reactor in a solution of $0.05 \mathrm{M} \mathrm{Na}_{2} \mathrm{SO}_{4}$, with a flow rate of $56 \mathrm{~L} / \mathrm{h}$ and a current density of (A) $100 \mathrm{~mA} / \mathrm{cm}^{2}$, (B) $200 \mathrm{~mA} / \mathrm{cm}^{2}$, (C) $300 \mathrm{~mA} / \mathrm{cm}^{2}$. 
curve $2(\mathrm{C})$ shows a current density of $300 \mathrm{~mA} / \mathrm{cm}^{2}$, which resulted in $133 \mathrm{mg} / \mathrm{L} \mathrm{H}_{2} \mathrm{O}_{2}$.

In all cases, it can be seen that the $\mathrm{H}_{2} \mathrm{O}_{2}$ concentration is directly proportional to the current density supplied to the system. On the other hand, the $\mathrm{H}_{2} \mathrm{O}_{2}$ concentration did not increase linearly with reaction time; after about $80 \mathrm{~min}$, the $\mathrm{H}_{2} \mathrm{O}_{2}$ concentration reached its plateau value and remained almost constant for the remainder of the reaction time. These results are in accordance whit previously reported [33]. From these results, it is apparent that $\mathrm{H}_{2} \mathrm{O}_{2}$ undergoes chemical decomposition $\mathrm{O}_{2}$ either on the anode (heterogeneous process) or in the medium (homogeneous process) [34,35]:

$$
\begin{aligned}
& \mathrm{H}_{2} \mathrm{O}_{2} \rightarrow \mathrm{HO}_{2}^{-}+\mathrm{H}^{+}+\mathrm{e}^{-} \\
& \mathrm{HO}_{2}^{+} \rightarrow \mathrm{O}_{2(g)}+\mathrm{H}^{+}+\mathrm{e}^{-}
\end{aligned}
$$

An additional set of assays was carried out in which the flow rate was increased to $76 \mathrm{~L} / \mathrm{h}$, and the three current densities used in the previous assay were maintained. The results of this study are presented in Figure 3. In these experiments, $\mathrm{H}_{2} \mathrm{O}_{2}$ generation is favored by the increased the flow rate. The $\mathrm{H}_{2} \mathrm{O}_{2}$ concentration was $75 \mathrm{mg} / \mathrm{L}$ after $180 \mathrm{~min}$ of reaction when a current density of $100 \mathrm{~mA} / \mathrm{cm}^{2}$ was applied, $166 \mathrm{mg} / \mathrm{L}$ when a current density of $200 \mathrm{~mA} / \mathrm{cm}^{2}$ was applied, $268 \mathrm{mg} / \mathrm{L}$ when a current density of $300 \mathrm{~mA} / \mathrm{cm}^{2}$ was applied. In this last case, the maximal $\mathrm{H}_{2} \mathrm{O}_{2}$ concentration is larger than what was obtained with the same current density at the lower flow rate (Figure 2(C)).

To improve the efficiency of $\mathrm{H}_{2} \mathrm{O}_{2}$ generation, an additional flow rate of $96 \mathrm{~L} / \mathrm{h}$ was tested using the same three current densities as before. The results are presented in Figure 4. As in the previous tests, for current densities of $100 \mathrm{~mA} / \mathrm{cm}^{2}$ and $200 \mathrm{~mA} / \mathrm{cm}^{2}$, the $\mathrm{H}_{2} \mathrm{O}_{2}$ concentration is directly proportional to the applied charge, generating $54 \mathrm{mg} / \mathrm{L}$ (curve 4(A)) and $104 \mathrm{mg} / \mathrm{L}$ (curve 4(B)) after $180 \mathrm{~min}$ of reaction, respectively. However, when the current density was $300 \mathrm{~mA} / \mathrm{cm}^{2}$ (curve 4(C)), the $\mathrm{H}_{2} \mathrm{O}_{2}$ concentration is drastically decreased relative to concentration obtained with the lower current densities. The maximal accumulation is approximately $95 \mathrm{mg} / \mathrm{L}$ after $180 \mathrm{~min}$

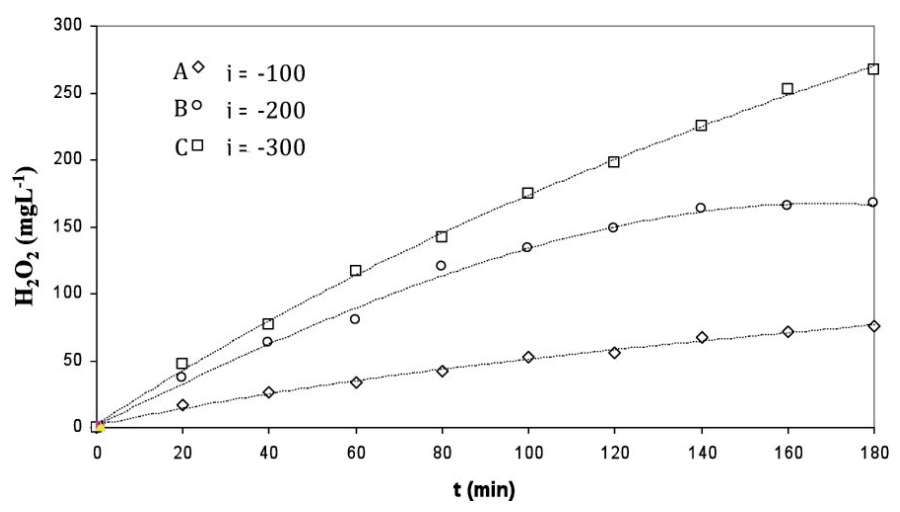

Figure 3. $\mathrm{H}_{2} \mathrm{O}_{2}$ production in the photo-electrochemical reactor in a solution of $0.05 \mathrm{M} \mathrm{Na}_{2} \mathrm{SO}_{4}$ with a flow rate of $76 \mathrm{~L} / \mathrm{h}$. The current densities were (A) $100 \mathrm{~mA} / \mathrm{cm}^{2}$, (B) $200 \mathrm{~mA} / \mathrm{cm}^{2}$ and (C) $300 \mathrm{~mA} / \mathrm{cm}^{2}$.

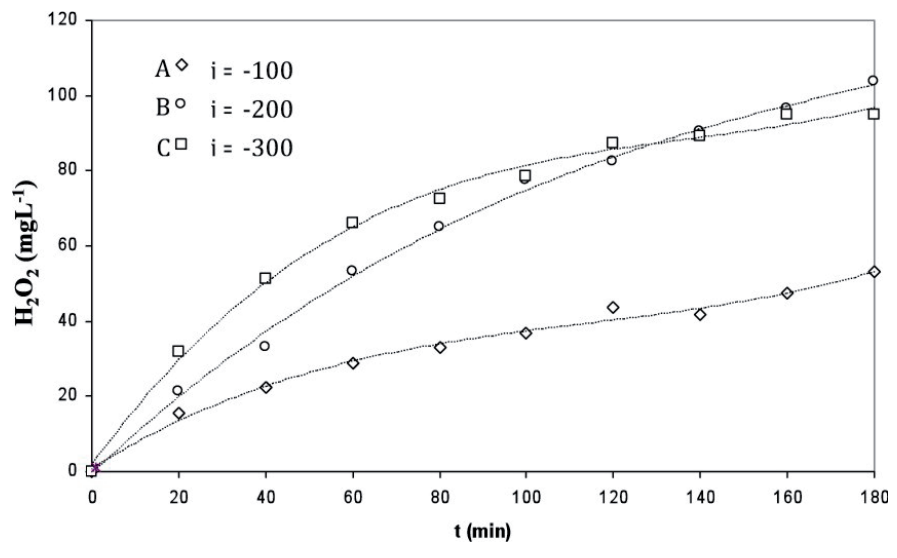

Figure 4. $\mathrm{H}_{2} \mathrm{O}_{2}$ production in the photo-electrochemical reactor in a solution of $0.05 \mathrm{M} \mathrm{Na}_{2} \mathrm{SO}_{4}$ with a flow rate of $96 \mathrm{~L} / \mathrm{h}$. The current densities were (A) $100 \mathrm{~mA} / \mathrm{cm}^{2}$, (B) $200 \mathrm{~mA} / \mathrm{cm}^{2}$ and (C) $300 \mathrm{~mA} / \mathrm{cm}^{2}$.

of reaction, a value that is smaller than what was obtained with a current density of $200 \mathrm{~mA} / \mathrm{cm}^{2}$. A possible explanation for this phenomenon is the mass transfer coefficient of the $\mathrm{H}_{2} \mathrm{O}_{2}$ formation in the system.

The shape of the curves can be explained by considering the gradual accumulation of $\mathrm{H}_{2} \mathrm{O}_{2}$ that must be associated with its proportional decomposition in a complex process that probably includes both homogeneous and heterogeneous reactions. Equation 13 for instance, shows that although the rate of $\mathrm{H}_{2} \mathrm{O}_{2}$ production depends on the interfacial activity of the $\mathrm{O}_{2}$ at the cathode and on the corresponding electrode transfer rate constant, $k_{1}$, decomposition can be assumed to depend on heterogeneous and homogeneous processes taking place at both the anode and the cathode. In this way, the combined decomposition rate is a function of the corresponding rate constants, $k_{2}, k_{3}, k_{4}$ and $k_{5}$ ( $k_{2}$ and $k_{4}$ for homogeneous and $k_{3}$ and $k_{5}$ for heterogeneous processes) and of the local activity of $\mathrm{H}_{2} \mathrm{O}_{2}$ at either the cathode or the anode $\left(\left[\mathrm{H}_{2} \mathrm{O}_{2}\right]_{0, c}\right.$ and $\left[\mathrm{H}_{2} \mathrm{O}_{2}\right]_{0, a}$, respectively).

$$
\begin{aligned}
\frac{d\left[\mathrm{H}_{2} \mathrm{O}_{2}\right]_{0}}{d t} & =k_{1}\left[\mathrm{O}_{2}\right]_{0, c}-k_{2}\left[\mathrm{H}_{2} \mathrm{O}_{2}\right]_{f, c}-k_{3}\left[\mathrm{H}_{2} \mathrm{O}_{2}\right]_{0, c} \\
& -k_{4}\left[\mathrm{H}_{2} \mathrm{O}_{2}\right]_{f, a}-k_{5}\left[\mathrm{H}_{2} \mathrm{O}_{2}\right]_{0, a}
\end{aligned}
$$

The activities of the compounds in the interfacial electrode solution in Equation $13\left(\left[\mathrm{O}_{2}\right]_{0, c},\left[\mathrm{H}_{2} \mathrm{O}_{2}\right]_{0, c}\right.$ and $\left.\left[\mathrm{H}_{2} \mathrm{O}_{2}\right]_{0, a}\right)$ can be associated with those in the bulk solution $\left(\left[\mathrm{O}_{2}\right]_{\text {sol }}\right.$ and $\left.\left[\mathrm{H}_{2} \mathrm{O}_{2}\right]_{\text {sol }}\right)$ by assuming a linear relationship between the two activity values through a mass transfer-related constant, which allows factorization and reduction of Equation 13 to Equation 14, in which two new constants, $k^{\prime}$ and $k^{\prime \prime}$, contain information on the kinetic and mass transport properties of the system.

$$
\frac{d\left[\mathrm{H}_{2} \mathrm{O}_{2}\right]_{s o l}}{d t}=k^{\prime}\left[\mathrm{O}_{2}\right]_{s o l}-k^{\prime \prime}\left[\mathrm{H}_{2} \mathrm{O}_{2}\right]_{s o l}
$$

Evaluation of this differential equation results in Equation 15, which demonstrates that the concentration of $\mathrm{H}_{2} \mathrm{O}_{2}$ in the 
bulk solution follows an exponential relationship with time, which describes the behavior of each of the curves.

$$
\left[\mathrm{H}_{2} \mathrm{O}_{2}\right]_{\text {sol }}=\left(\frac{k^{\prime}\left[\mathrm{O}_{2}\right]_{s o l}}{k^{\prime \prime}}\right)\left(1-\mathrm{e}^{-k^{\prime \prime} t}\right)
$$

We applied Equations 13 to 15 to the results from the experiment with a flow rate of $76 \mathrm{~L} / \mathrm{h}$ because this experiment shows a define tendency than those with flow rates of $56 \mathrm{~L} / \mathrm{h}$ and $96 \mathrm{~L} / \mathrm{h}$. The corresponding adjustments are shown in Figure 5, and the resulting values of $k^{\prime}$ and $k^{\prime \prime}$ are presented in Table 1.

The results presented in Table 1 demonstrate that the greatest $\mathrm{H}_{2} \mathrm{O}_{2}$ production takes place when a current density of 300 $\mathrm{mA} / \mathrm{cm}^{2}$ and a flow rate of $76 \mathrm{~L} / \mathrm{h}$ are applied. Under these conditions, $k$ " is greater than $k^{\prime}$, and therefore the decomposition of $\mathrm{H}_{2} \mathrm{O}_{2}$ is inhibited.

At very long reaction times, Equation 15 predicts that the concentration of $\mathrm{H}_{2} \mathrm{O}_{2}$ loses its dependence on time (as shown in Equation 16), reaching a constant value that depends only on the constants, $k^{\prime}$ and $k^{\prime \prime}$, and the concentration of dissolved $\mathrm{O}_{2}$ in the electrolytic medium.

$$
\underset{\lim t \rightarrow \infty}{\left[\mathrm{H}_{2} \mathrm{O}_{2}\right]_{\text {sol }}}=\frac{k^{\prime}\left[\mathrm{O}_{2}\right]_{\text {sol }}}{k^{\prime \prime}}
$$

This preliminary model predicts that operating under mass transfer conditions of the electrochemical reactor controls the limiting concentration of $\mathrm{H}_{2} \mathrm{O}_{2}$ that can be produced because the concentration of $\mathrm{O}_{2}$ in the medium is saturated and can be assumed to be constant.

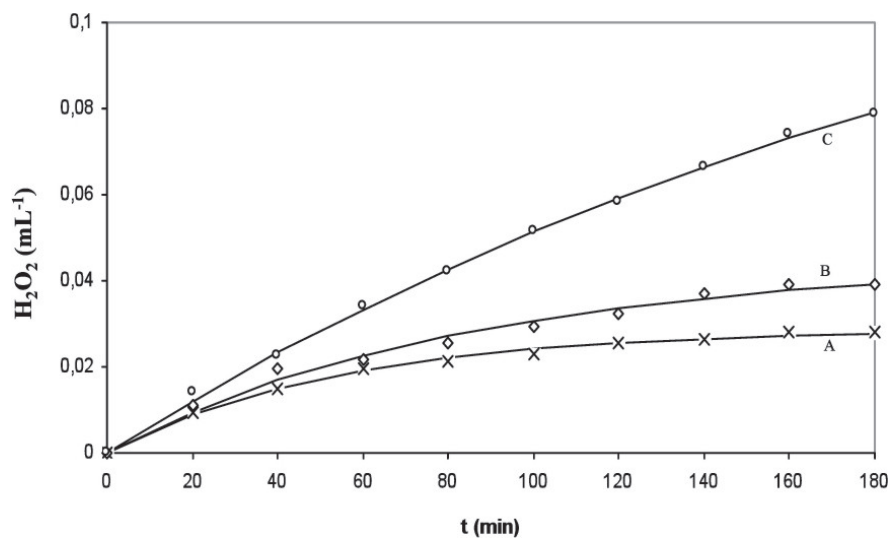

Figure 5. Simulated values obtained with a flow rate of $76 \mathrm{~L} / \mathrm{h}$ and current densities of (A) $100 \mathrm{~mA} / \mathrm{cm}^{2}$, (B) $200 \mathrm{~mA} / \mathrm{cm}^{2}$, and (C) 300 $\mathrm{mA} / \mathrm{cm}^{2}$.

Table 1. $k^{\prime}$ and $k$ ', values that were obtained with the mathematical model in Equation 13.

\begin{tabular}{ccc}
\hline $\mathrm{j}\left(\mathrm{mA} / \mathrm{cm}^{2}\right)$ & $\mathrm{k}^{\prime}$ & $\mathrm{k}^{\prime \prime}$ \\
\hline 100 & 0,0179 & 0,0255 \\
200 & 0,0119 & 0,0391 \\
200 & 0,1300 & 0,0042 \\
\hline
\end{tabular}

\section{Degradation of OG-II by the EF and PEF processes}

Studies of OG-II oxidation by electrically generated $\mathrm{H}_{2} \mathrm{O}_{2}$ were carried out with a current density of $300 \mathrm{~mA} / \mathrm{cm}^{2}$ and a flow rate of $76 \mathrm{~L} / \mathrm{h}$. In these experiments, two $\mathrm{Fe}^{2+}$ concentrations, $0.02 \mathrm{mM}$ and $0.05 \mathrm{mM}$, in a total volume of $27 \mathrm{~L}$ were used. In both cases, the process started with an initial $\mathrm{H}_{2} \mathrm{O}_{2}$ concentration of $250 \mathrm{mg} / \mathrm{L}$. Figure 6(A) shows the HPLC analysis of a solution containing $50 \mathrm{mg} / \mathrm{L}$ of OG-II treated with the EF system with a $\mathrm{Fe}^{2+}$ concentration of $0.02 \mathrm{mM}$, and Figure 6(B) shows the results for the PEF process under the same conditions. The results show that both the EF and PEF systems completely decolorize the OG-II system after $5 \mathrm{~min}$ of treatment, indicating that both are very effective for removing organic compound OG-II.
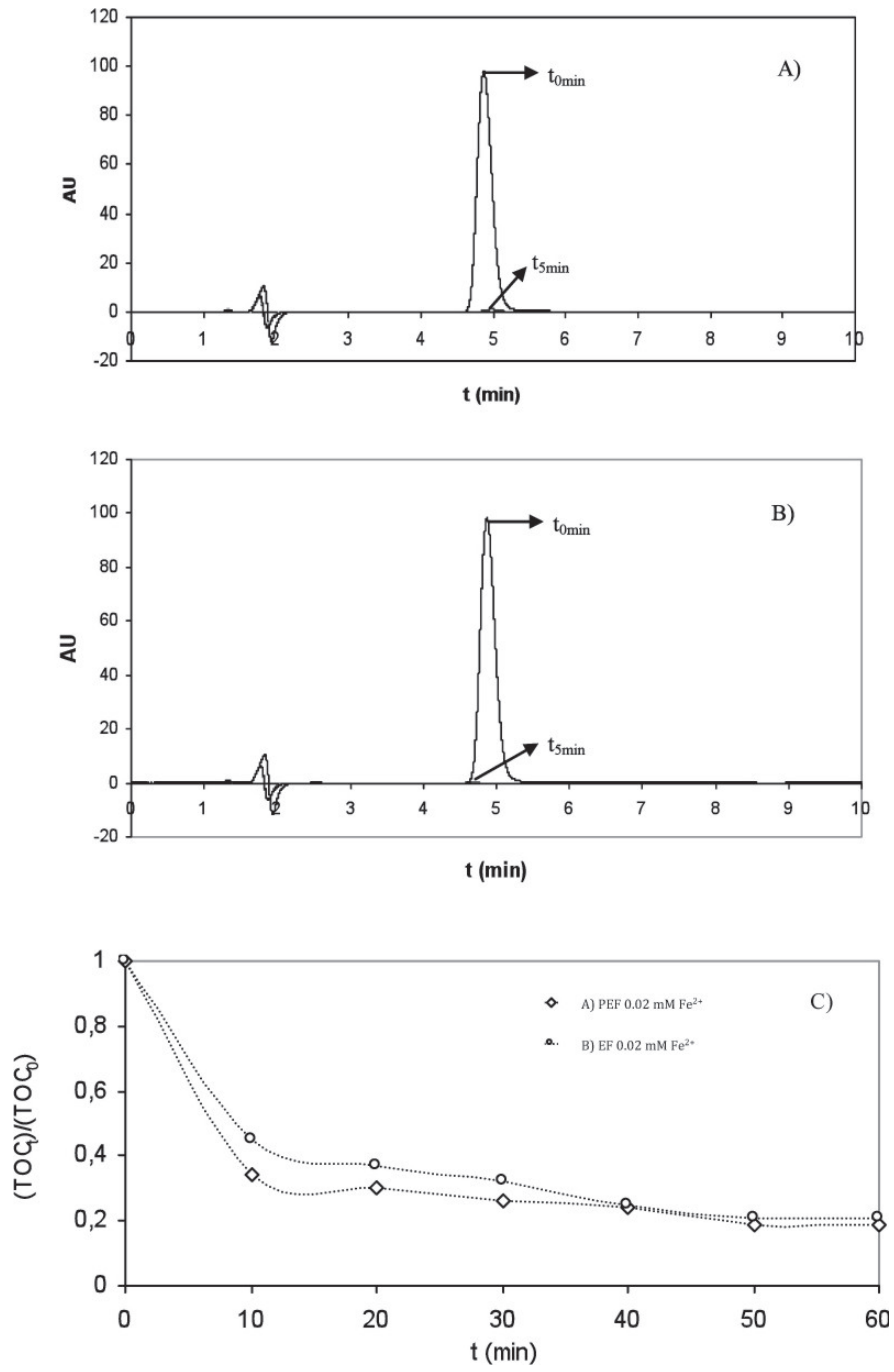

Figure 6. Degradation of $50 \mathrm{mg} / \mathrm{L}$ OG-II dye with the (a) EF assay and (b) PEF assay, $\left[\mathrm{H}_{2} \mathrm{O}_{2}\right]_{0}=250 \mathrm{mg} / \mathrm{L}$ with $0.02 \mathrm{mM} \mathrm{Fe}^{2+}$ at different sampling times, measured under the following conditions: $\lambda=487 \mathrm{~nm}$, mobile phase: $\mathrm{ACNH}_{4} 68 \%$, ACN $32 \%$ and flow rate $=0.5 \mathrm{~mL} / \mathrm{min}$. (c) TOC removal in the $50 \mathrm{mg} / \mathrm{L}$ OG-II dye solution in the (i) PEF system and (ii) EF system, $\left[\mathrm{H}_{2} \mathrm{O}_{2}\right]=250 \mathrm{mg} / \mathrm{L}, 0.02 \mathrm{mM} \mathrm{Fe}^{2+}, \mathrm{pH}=3$, volume $=27 \mathrm{~L}$, flow rate $=76 \mathrm{~L} / \mathrm{h}$, current density $=300 \mathrm{~mA} / \mathrm{cm}^{2}$. 
Figure 6(C) shows TOC removal as a function of time for both the EF and PEF systems. With an $\mathrm{Fe}^{2+}$ concentration of $0.02 \mathrm{mM}$, the mineralization level of the OG-II dye was approximately $80 \%$ after $60 \mathrm{~min}$ of treatment with either the $\mathrm{EF}$ or PEF system. This phenomenon is caused by the photoreduction of $\mathrm{Fe}(\mathrm{OH})^{2+}$ complexes to $\mathrm{Fe}^{2+}$, which increases the production of ${ }^{\bullet} \mathrm{OH}$ oxidant species in the medium, in accordance with Equation 4.

To estimate the effect of the $\mathrm{Fe}^{2+}$ concentration on the removal of the OG-II dye, a greater $\mathrm{Fe}^{2+}$ concentration $(0.05$ $\mathrm{mM}$ ) was tested in a similar manner using both the EF and PEF systems. The results of these experiments are presented in Figure 7.
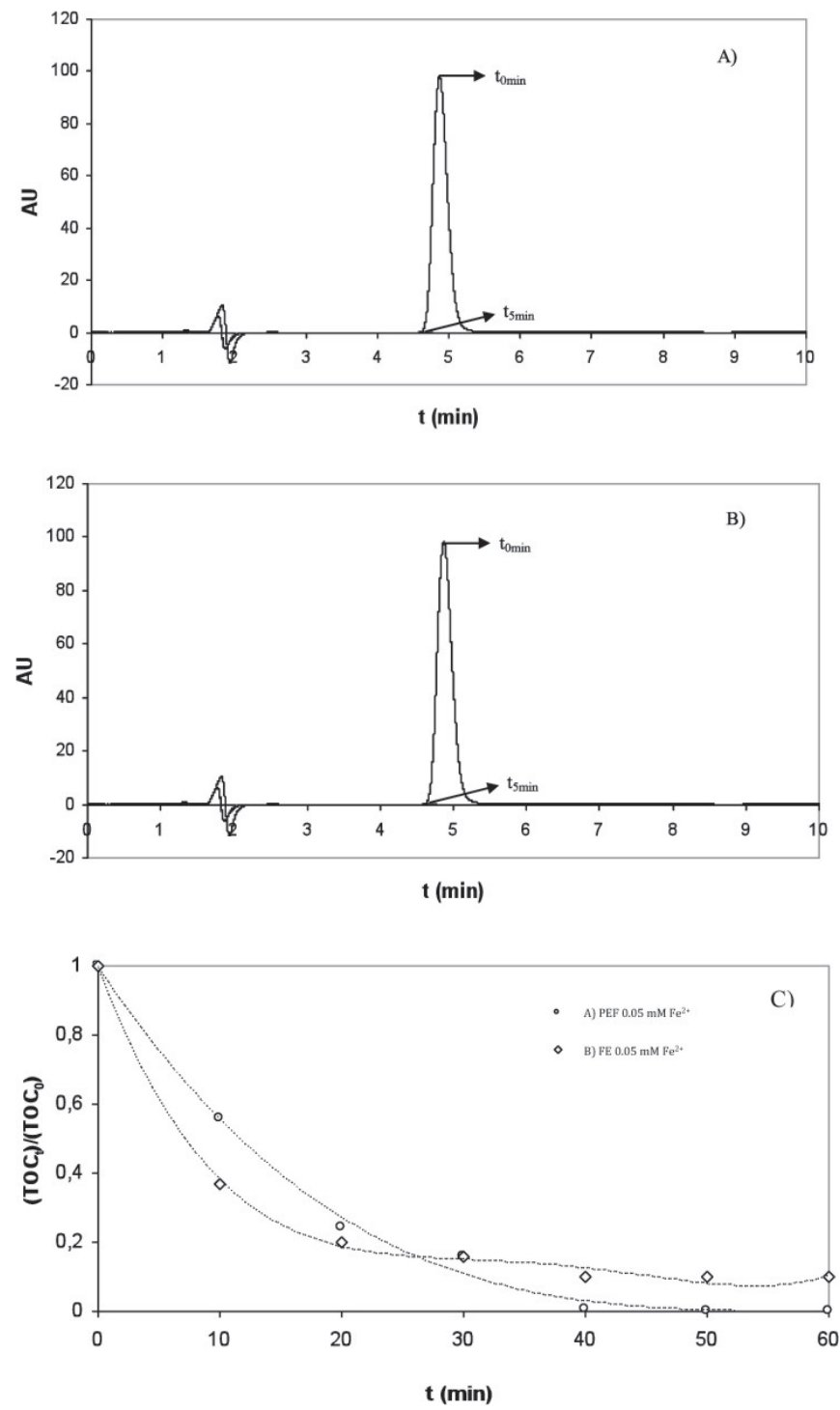

Figure 7. Degradation of $50 \mathrm{mg} / \mathrm{L}$ OG-II dye with the (a) EF assay and (b) PEF assay, $\left[\mathrm{H}_{2} \mathrm{O}_{2}\right]_{0}=250 \mathrm{mg} / \mathrm{L}$ and $0.05 \mathrm{mM} \mathrm{Fe}^{2+}$ at different sampling times, measured under the following conditions: $\lambda=487 \mathrm{~nm}$, mobile phase: $\mathrm{ACNH}_{4} 68 \%$, ACN $32 \%$ and flow rate $0.5 \mathrm{~mL} / \mathrm{min}$. (c) TOC removal in the $50 \mathrm{mg} / \mathrm{L}$ OG-II dye solution in the (i) PEF system and (ii) EF system, $\left[\mathrm{H}_{2} \mathrm{O}_{2}\right]=250 \mathrm{mgL}^{-1}, 0.05 \mathrm{mM} \mathrm{Fe}^{2+}, \mathrm{pH}=3$, volu$\mathrm{me}=27 \mathrm{~L}$, flow rate $=76 \mathrm{~L} / \mathrm{h}$, current density $=300 \mathrm{~mA} / \mathrm{cm}^{2}$.
The HPLC analysis of the OG-II dye dissolution carried out with an $\mathrm{Fe}^{2+}$ concentration of $0.05 \mathrm{mM}$ by EF and PEF is shown in Figures 7(A) and 7(B), respectively. For each method, samples were collected at a number of time points during the experiment for quantification of OG-II dye presence by HPLC. Again, it is evident that the oxidation of the OG-II dye using either the EF or the PEF process is efficient because the color is removed, as seen by the decrease in signal at a wavelength of $487 \mathrm{~nm}$.

To measure the mineralization by these two processes of the OG-II dye, analysis of TOC was carried out. The results are shown in Figure 7(C). When the $\mathrm{Fe}^{2+}$ concentration was 0.05 $\mathrm{mM}$, the mineralization of the OG-II dye is improved compared to the lower $\mathrm{Fe}^{2+}$ concentration $(0.02 \mathrm{mM})$, with, TOC removal close to $90 \%$ for the EF system and $100 \%$ for the PEF process after $60 \mathrm{~min}$ of treatment.

Incorporation of a Nafion ${ }^{\mathrm{TM}}$ membrane with an immobilized iron catalyst in the photo-electrochemical reactor

In this part of the work, a Nafion ${ }^{\mathrm{TM}}$ membrane was incorporated into the system to avoid the need for $\mathrm{Fe}^{2+}$ addition to the solution and to promote photo-assisted processes that can be used to mineralize pollutants. In Figure 8, we show a SEM image of a membrane that was prepared by the method of Kiwi et al. [20-22]. Figure 8(A) shows the membrane without $\mathrm{Fe}^{2+}$ in the lattice, and Figure 8(B) shows the membrane with $\mathrm{Fe}^{2+}$. It is clear that the dispersion of $\mathrm{Fe}^{2+}$ over the membrane lattice is homogeneous and is in the form of clusters. The $\mathrm{Fe}^{2+}$ fixed in the Nafion ${ }^{\mathrm{TM}}$ membrane is excited by UV light, forming ${ }^{\bullet} \mathrm{OH}$ radicals via $\mathrm{H}_{2} \mathrm{O}_{2}$ decomposition [22].

Incorporation of carbon fibers coated with $\mathrm{TiO}_{2}$ films in the photo-electrochemical reactor

A new innovation of this photo-electrochemical reactor is the incorporation of $\mathrm{TiO}_{2}$ electrodes to promote photocatalytic phenomena to improve organic compound removal [36]. Figure 9 shows the SEM images of the $\mathrm{TiO}_{2}$-carbon cloth electrodes that were prepared by electrophoretic deposition. As shown in Figure 9(A), the $\mathrm{TiO}_{2}$ deposits (40 s deposition time) were not completely homogeneous, and in some places, the surface of the uncoated carbon cloth can be observed. However, when the electrophoretic deposition time was increased to $60 \mathrm{~s}$, the

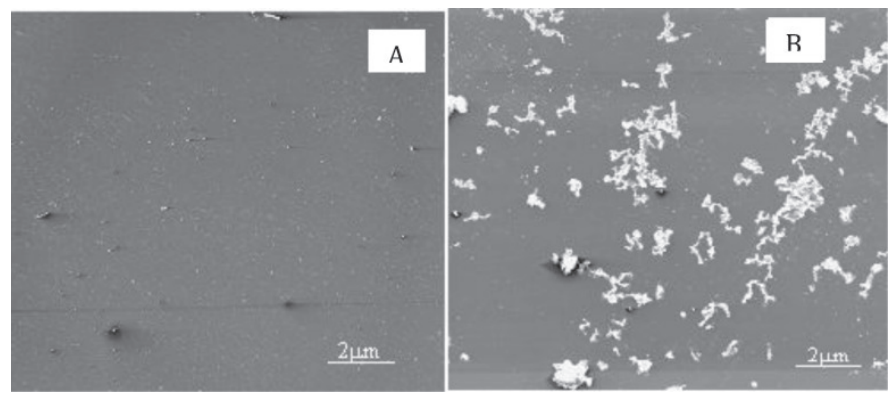

Figure 8. SEM images of (a) a Nafion ${ }^{\mathrm{TM}}$ membrane without $\mathrm{Fe}^{2+}$ and (b) a Nafion ${ }^{\mathrm{TM}}$ membrane with $\mathrm{Fe}^{2+}$ clusters in the lattice. 


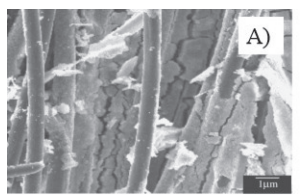

40 seg

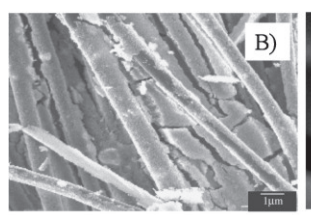

$60 \operatorname{seg}$

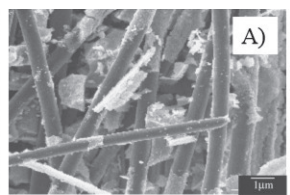

40 seg

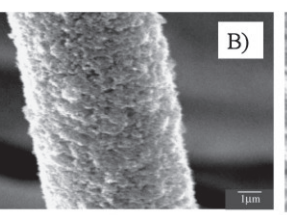

60 seg

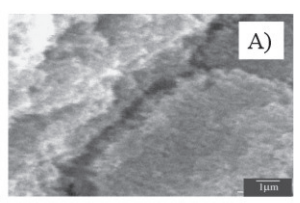

40 seg

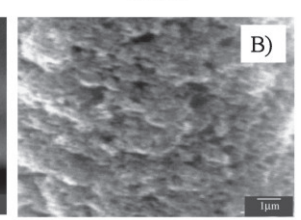

$60 \mathrm{seg}$
Figure 9. SEM images of carbon cloth fibers coated with $\mathrm{TiO}_{2}$. (a) Deposition time of $40 \mathrm{~s}, \mathrm{~T}=450{ }^{\circ} \mathrm{C}$ for $30 \mathrm{~min}$. (b) Deposition time of $60 \mathrm{~s}, \mathrm{~T}=450{ }^{\circ} \mathrm{C}$ for $30 \mathrm{~min}$.

coverage was uniform over the carbon cloth lattice, as shown in Figure 9(B).

\section{Removal of coliforms in the photo-electrochemical reactor} using a $\mathrm{Nafion}^{\mathrm{TM}}$ membrane with dispersed iron, $\mathrm{TiO}_{2}$-carbon cloth electrode and continuous $\mathrm{H}_{2} \mathrm{O}_{2}$ electrogeneration

To evaluate the capacity of the new photo-electrochemical reactor to remove coliforms from an effluent stream, several tests were performed with wastewater supplied from a municipal network. The experiment was carried out in the presence of $\mathrm{H}_{2} \mathrm{O}_{2}$ that was continuously electro-generated in the system with an $\mathrm{Fe}^{2+}$-fixed Nafion ${ }^{\mathrm{TM}}$ membrane and a $\mathrm{TiO}_{2}$-carbon cloth anode. The system was continuously illuminated to promote the photo-oxidation process. Figure 10 shows the coliform removal, reported with a presumptive water quality test, through determination of the most probable number (NMP) of total coliforms, fecal coliforms (thermal tolerants), and Escherichia coli. The new photo-electrochemical reactor removes $100 \%$ of the coliforms after $10 \mathrm{~min}$ of the oxidation process, indicating that the reactor is efficient in the removal of organic material in aqueous effluents.

These results are in accordance whit reported recently by S.N. Hussain, et al [37], where these authors carry out disinfec-

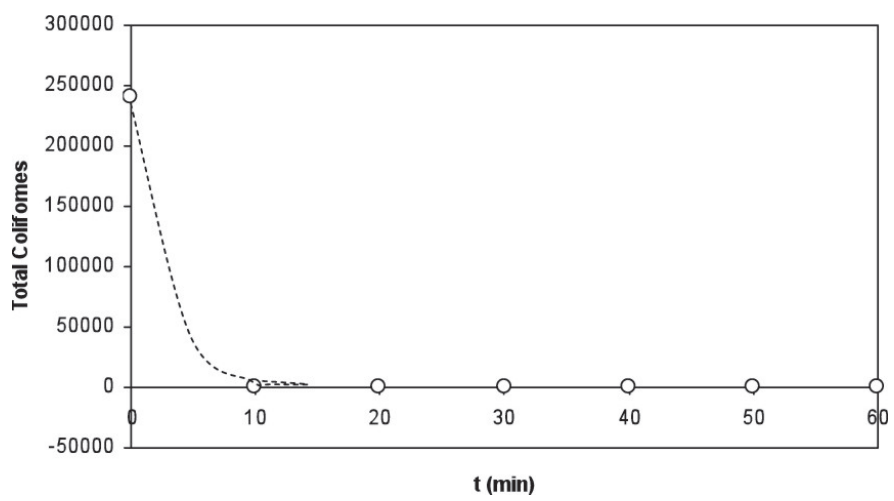

Figure 10. Abatement of total coliforms with time using the PEF system with an $\mathrm{Fe}^{2+}$-coated Nafion ${ }^{\mathrm{TM}}$ membrane and a $\mathrm{TiO}_{2}$-carbon cloth electrode. tion performance of a unique process of adsorption combined with electrochemical treatment.

\section{Conclusions}

The carbon cloth is an efficient material for $\mathrm{O}_{2}$ reduction and $\mathrm{H}_{2} \mathrm{O}_{2}$ formation. In this new photo-electrochemical reactor, the production of $\mathrm{H}_{2} \mathrm{O}_{2}$ reaches $260 \mathrm{mg} / \mathrm{L}$. Using dimensionless groups, we developed a general equation to scale-up the photoelectrochemical reactor. In the AOPs, the best $\mathrm{Fe}^{2+}$ concentration was $0.05 \mathrm{mM}$, resulting in $90 \%$ color removal of the OG-II dye. With the incorporation of a $\mathrm{Fe}^{2+}$-fixed Nafion ${ }^{\mathrm{TM}}$ membrane and a $\mathrm{TiO}_{2}$-carbon cloth anode, the system performs better than without these additions, with a measured coliform bacteria removal ability of $100 \%$.

\section{Acknowledgments}

The authors wish to thank the CONACyT for financial support this research.

\section{References}

1. Da Pozzo, A.; Di Palma, L.; Merli, C.; Petrucci. E. J. Appl. Electrochem. 2005, 35, 413-419.

2. Da Pozzo, A.; Ferrantelli, P.; Merli, C.; Petrucci, E. J. Appl. Electrochem. 2005, 35, 391-398.

3. Isarain-Chávez, E.; de la Rosa, C.; Martínez-Huitle, C.A.; PeraltaHernández, J.M. Int. J. Electrochem. Sci. 2013, 8, 3084-3094.

4. Badellino, C.; Arruda Rodrigues, C.; Bertazzoli, R. J. Hazard Mat. 2006, 137, 856-864.

5. Martínez-Huitle, C.A.; Brillas, E. Appl. Cat. B: Environ. 2009, 1 87, 105-145.

6. Cruz-González, K.; Torres-Lopez, O.; García-León, A.M.; Brillas, E.; Hernández-Ramírez, A.; Peralta-Hernández, J.M. Desalination 2012, 286, 63-68.

7. Skoumal, M.; Rodriguez, R.M.; Lluis Cabot, P.; Centellas, F.; Garrido, J.A.; Arias, C.; Brillas, E. Electrochim. Acta 2009, 54, 2077-2085.

8. Peralta-Hernández, J.M.; Meas-Vong, Y.; Rodríguez, F.J.; Chapman, T.W.; Maldonado, M.I.; Godínez, L.A. Dyes and Pigments 2008, 76, 656-662.

9. El-Ghenymy, A.; Oturan, N.; Oturan, M.A.; Garrido, J.A.; Cabot, P.L.; Centellas, F.; Rodríguez, R.M.; Brillas, E. Chem. Eng. J, 2013, 234, 115-123.

10. Peralta-Hernández, J.M.; Martínez-Huitle, C. A.; Guzmán-Mar, J. L.; Hernández-Ramírez, A. J. Environ. Eng. Manage 2009, 19, 257-265.

11. Peralta-Hernández, J.M.; Meas-Vong, Y.; Rodríguez, F.J.; Chapman, T.W.; Maldonado, M.I.; Godínez, L.A. Water Res. 2006, 40, 1754-1762.

12. Cruz-González, K.; Torres-López, O.; García-León, A.; GuzmánMar, J.L.; Reyes, L.H.; Hernández-Ramírez, A.; Peralta-Hernández, J.M. Chem. Eng. J. 2010, 160, 199-206.

13. Melgoza, D.; Hernández-Ramírez, A.; Peralta-Hernández, J. M.; Photochem. Photobiol. Sci. 2009, 8, 596-599.

14. Anotai, J.; Lu M-Ch.; Chewpreecha, P. Water Res. 2006, 40, 1841 1847. 
15. Esquivel, K.; Arriaga, L.G.; Rodríguez, F.J.; Martínez, L.; Godínez, L.A. Water Res. 2009, 43, 3593-3603.

16. Özcan, A.; Oturan, M.A.; Oturan, N.; Sahin, Y. J. Hazard. Mat. 2009, 163, 1213-1220.

17. Guinea, E.; Arias, C.; Lluís Cabot, P.; Garrido, J.A.; Rodríguez, R.M.; Centellas, F.; Brillas, E. Water Res. 2008, 42, 499-511.

18. Xie, Y.B.; L, X.Z. Mat. Chem. Phys. 2006, 95, 39-50.

19. Isarain-Chávez, E.; Rodríguez, R.M.; Cabot, P.L.; Centellas, F.; Arias, C.; Garrido, J.A.; Brillas, E. Water Res. 2011, 45, 41194130.

20. Fernandez, J.; Bandara, J.; Lopez, A.; Buffat, Ph.; Kiwi, J. Langmuir 1999, 15, 185-192.

21. Fernandez, J.; Bandara, J.; Lopez, A.; Albers, P.; Kiwi, J. Chem. Com. 1998, 1493.

22. Balanosky, E.; Fernandez, J.; Kiwi, J.; Lopez, A. Wat. Sci. Tech. 1999, 40, 417- 424.

23. Rizzo, L.; Koch, J.; Belgiorno, V.; Anderson, M.A. Desalination 2007, 211, 1-9.

24. Fujishima, A.; Rao, T.N.; Tryk, D.A. J. Photochem. Photobiol. C: Photochem. Rev. 2000, 1, 1-21.

25. Gogate, P. R.; Pandit, A. B. Adv. Env. Res. 2004, 8, 501-551.

26. Sheng, H.; Li, Q.; Wanhong, Ma.; Hongwei, Ji.; Chuncheng, Ch.;
Jincai, Z. Appl. Cat. B: Environ. 2013, 138, 212-218.

27. Pelizzetti, E.; Minero, C. Electrochim. Acta. 1993, 38, 47-55.

28. Villanueva-Rodríguez, M.; Hernández-Ramírez, A.; PeraltaHernández, J.M.; Bandala, E.R.; Quiroz-Alfaro, M.A. J. Haz. Mat. 2009, 167, 1226-1230.

29. Keller, N.; Rebmann, G.; Barraud, E.; Zahraa, O.; Keller, V.; Cat. Today. 2005, 101, 323-329.

30. Pak, D.; Chung, D.; Beck Ju, J. Water Res. 2001, 35, 57-68.

31. Eisenberg, G.M. Ind. Eng. Chem. 1943, 15, 327-328.

32. Manriquez, J.; Godínez, L.A. Thin Solid Films. 2007, 515, 34023413.

33. Orlando García, Eloy Isarain-Chávez, Sergi Garcia-Segura, Enric Brillas, Juan M. Peralta-Hernández. Electrocatalysis 2013, 4, 224-234.

34. García, O.; Isarain-Chávez, E.; Garcia-Segura, S.; Brillas, E.; Peralta-Hernández, J.M. Electrocatalysis. 2013, 4, 224-234.

35. Garcia-Segura, S.; Brillas, E. Water Res. 2011, 45, 2975-2984.

36. Peralta-Hernández, J.M.; Manríquez, J.; Meas-Vong, Y.; Rodriguez Francisco, J.; Chapman, T.W.; Maldonado, M.I.; Godínez, L.A. J. Hazard. Mat. 2007, 147, 588-593.

37. Hussain, S.N.; de las Heras, N.; Asghar, H.M.A.; Brown, N.W.; Roberts, E.P.L. Water Res. 2014, 54, 170-78. 